Journal of Borneo Social Transformation Studies (JOBSTS), Vol. 5. No. 1, 2019

ISSN 2462-2095

Universiti Malaysia Sabah

\title{
DASAR PERBURUHAN DAN IMPAKNYA TERHADAP PERGERAKAN KESATUAN SEKERJA DI MALAYSIA:SATU KAJIAN AWAL
}

\author{
LABOUR POLICY AND ITS IMPACT ON THE MOVEMENT OF TRADE UNION IN \\ MALAYSIA: A PRELIMINARY STUDY
}

\author{
Mahadirin Ahmad, Kee.Y.Sabariah Kee Mohd Yussof, Noor Syakirah Zakaria \\ Program Hubungan Industri, \\ Fakulti Kemanusiaan Seni dan Warisan \\ Universiti Malaysia Sabah \\ muhadiri@ums.edu.my
}

\begin{abstract}
The development of the labour movement and the industry relations scenario in Malaysia began in the 1920s, which were influenced by the British administration policies in Malaya. Since then, the trade unions continued to grow in Malaya and experienced a process of change because of the control measures and various restrictions including the Emergency Law in 1948. The policies and controls were practiced until the country gained independence in 1957. Based on the literature review, there are certain changes in the labour policy based on the country's highest leadership, the Prime Minister, which also affects the industrial relations system in Malaysia. Since independence, the leader or the first Prime Minister of Malaysia, Tunku Abdul Rahman had shaped the industrial relations system from a voluntary system to a compulsory arbitration through the enactment of the Industrial Relations Act, 1967. Meanwhile, changes have taken place during the reign of the second Prime Minister, Tun Abdul Razak, who introduced the accommodation system between the trade union and the employers. The next change occurred in 1976 when Tun Hussein Onn drafted a more stringent labour policy on the trade union movement. Change continued through the new leadership in 1981 under the administration of Tun Dr. Mahathir Muhammad who introduced various policies to support the country's industrial process. Among them is the Look East policy that promotes the existence of internal trade unions. In addition, the use of the Internal Security Act (ISA) has also been extended to control union leaders who tend to be conflicted. The next change occurred in the era of Tun Abdullah's administration, which introduced the Islamic administration pattern through Islam Hadari practices since 2003. The next stage is under the administration of Datuk Seri Mohd Najib Tun Razak, who had introduced national transformation and the 1 Malaysia concept. The final stage is in the New Malaysia era under the leadership of Tun Dr Mahathir Mohammad after Pakatan Harapan's 2018 victory in the $14^{\text {th }}$ general election. Based on these scenarios, this paper aims to explain the changes in the government policies, and the level of acceptance of the trade unions
\end{abstract}


during the reign of all the six Prime Ministers. Finally, the analysis of these changes will be discussed in terms of their implications on the sustainability of trade unions that influences the pattern of industrial relations in Malaysia.

Keywords: Leader,Trade Union, Industrial Relations, Labour Policies.

\begin{abstract}
ABSTRAK
Perkembangan pergerakan buruh dan senario hubungan industri di Malaysia telah bermula sejak tahun 1920-an lagi yang turut dipengaruhi oleh dasar pentadbiran British di Tanah Melayu. Sejak detik itu, kesatuan sekerja terus berkembang di Tanah Melayu dan mengalami proses perubahan kesan tindakan kawalan dan pelbagai sekatan termasuklah pengenalan Undang-undang Darurat pada Tahun 1948.Dasar kawalan dan sekatan tersebut terus diamalkan sehingga negara mencapai kemerdekaan pada tahun 1957. Berdasarkan tinjauan terhadap sorotan literatur, terdapat perubahan-perubahan tertentu mengenai dasar perburuhan mengikut kepimpinan tertinggi negara iaitu Perdana Menteri yang turut mempengaruhi sistem hubungan industri di Malaysia. Sejak kemerdekaan dicapai, pemimpin atau Perdana Menteri Pertama di Malaysia iaitu Tunku Abdul Rahman telah mencorakkan sistem hubungan industri yang berubah dari sistem voluntary kepada corak compulsory arbitration melalui penguatkuasaan Akta Perhubungan Perusahaan, 1967. Manakala perubahan telah berlaku pada zaman pemerintahan Perdana Menteri kedua, iaitu Tun Abdul Razak yang telah memperkenalkan sistem akomodatif antara kesatuan sekerja dan majikan. Perubahan seterusnya berlaku pada tahun 1976 apabila Tun Hussien Onn telah menggubal dasar perburuhan yang lebih ketat ke atas pergerakan kesatuan sekerja. Perubahan terus berlaku melalui kepimpinan baru pada tahun 1981 di bawah pentadbiran Tun Dr. Mahathir Muhammad yang telah memperkenalkan pelbagai dasar bagi menyokong proses perindustrian negara. Antaranya ialah Dasar Pandang ke Timur yang telah menggalakkan kewujudan kesatuan sekerja dalaman. Selain itu, penggunaan Akta Keselamatan Dalam Negeri (ISA) turut diperluaskan bagi mengawal pemimpin kesatuan yang cenderung bersifat konfliktual. Perubahan seterusnya berlaku pada era pentadbiran Tun Abdullah yang memperkenalkan corak pentadbiran Islamik melalui amalan Islam Hadari sejak tahun 2003. Peringkat seterusnya adalah di bawah pentadbiran Datuk Seri Mohd. Najib Tun Abdul Razak yang memperkenalkan program transformasi negara dan konsep 1 Malaysia sejak tahun 2009. Peringkat terkahir ialah pada era Malaysia Baharu di bawah Pentadbiran Tun Dr. Mahathir Mohammad setelah kemenangan Pakatan Harapan dalam Pilihanraya Umum ke-14 pada tahun 2018. Berdasarkan senario tersebut, kertas kerja ini akan menjelaskan perubahan dasar kerajaan serta tahap penerimaan pergerakan kesatuan sekerja sepanjang era pemerintahan keenam-enam Perdana Menteri Malaysia. Akhirnya, analisis perubahan tersebut akan dibincangkan berkaitan implikasinya terhadap kelangsungan kesatuan sekerja yang turut mempengaruhi corak hubungan industri di Malaysia.
\end{abstract}


Journal of Borneo Social Transformation Studies (JOBSTS), Vol. 5. No. 1, 2019

ISSN 2462-2095

Universiti Malaysia Sabah

Kata Kunci : Pemimpin, Kesatuan Sekerja, Hubungan Industri, Dasar Perburuhan.

\subsection{Pengenalan}

Kesatuan sekerja berperanan untuk memperjuangkan kepentingan pekerja dari segi hak dan jaminan pekerjaan. Hak pekerja merangkumi beberapa perkara asas yang terkandung dalam syarat dan terma pekerjaan seperti upah, kebajikan dan isu keselamatan. Jaminan pekerjaan pula berkaitan perlindungan terhadap pemecatan atau pemberhentian yang tidak adil (Kee Mohd Yussof, Zakaria, \& Ahmad, 2015). Selain itu, dalam konteks yang lebih besar, kesatuan sekerja berperanan sebagai sebuah institusi untuk mengimbangi kuasa pihak majikan dan kuasa pihak pemerintah. Peranan ini merupakan faktor utama yang akan menentukan keberkesanan kesatuan dan seterusnya mempengaruhi pergerakan institusi tersebut. Selain itu, terdapat faktor lain yang mempengaruhi peranan tersebut seperti keadaan ekonomi, sikap pihak majikan dan dasar perburuhan oleh pemerintah menyebabkan pergerakan kesatuan sekerja turut mengalami perubahan.

Fenomena tersebut turut berlaku di Malaysia sejak era sebelum kemerdekaan iaitu sejak pentadbiran kerajaan British di Tanah Melayu dan masih dipraktikkan selepas pasca kemerdekaan. Perubahan terhadap dasar tersebut telah dilakukan sesuai dengan perubahan dasar pembangunan negara yang telah berubah tumpuan dari sektor pertanian kepada sektor perindustrian dan kini menuju ke arah negara maju. Perubahan yang berlaku menunjukkan satu kesinambungan corak kepimpinan tertinggi negara iaitu kuasa tertinggi bagi pemerintah yang bertanggungjawab untuk menggubal dasar-dasar berkaitan perburuhan di Malaysia.

Berdasarkan kesinambungan tersebut, objektif kertas kerja ini adalah untuk menjelaskan berkaitan pengaruh dasar perburuhan dan kesannya terhadap pergerakan kesatuan sekerja di Malaysia. Analisis perkembangan adalah berdasarkan tempoh perkhidmatan Perdana Menteri yang kini telah mencapai seramai enam orang dengan memberi tumpuan terhadap corak pentadbiran dan dasar berkaitan perburuhan yang utama. Namun begitu, penjelasan terhadap aspek persoalan dan objektif kajian akan dilakukan terlebih dahulu. Analisis seterusnya adalah terhadap dapatan kajian dan akhirnya berkaitan implikasi kajian.

\subsection{Permasalahan Dan Objektif Kajian}

Terdapat pelbagai kajian telah dilakukan berkaitan kesatuan sekerja di Malaysia yang melibatkan pelbagai tema dan isu berkaitan hubungan industri seperti kajian oleh Gamba (1962) Parmer (1957), Stenson, (1977), Jomo dan Todd (1994), Che Takwa (2004) dan Kee Mohd 
Yussof et al., (2015). Secara umum, dapat dinyatakan bahawa kesatuan sekerja telah berkembang sesuai dengan tahap kemajuan negara yang dahulunya adalah berasaskan ekonomi pertanian dan kini menuju ekonomi berasaskan pengetahuan. Sepanjang tempoh tersebut (1957 sehingga 2017) kesatuan sekerja terus wujud dan memainkan peranan yang penting untuk memperjuangkan kebajikan dan kepentingan golongan pekerja di Malaysia (Yussof, et al. 2015). Antara kejayaan kesatuan ialah pelaksanaan undang-undang berkaitan upah minimum pada tahun 2012 (Che Wan Abu Bakar, 2014). Namun begitu, terdapat banyak kritikan telah dilakukan terhadap kesatuan sekerja terutamanya berkaitan dasar dan undang-undang pekerjaan yang telah menyekat perkembangan kesatuan sekerja (Anantaraman, 1997; Arokia, 1991).

Salah satu kritikan terhadap dasar tersebut adalah berkait rapat dengan sekatan dan kawalan kepada para pekerja dalam berkesatuan (Anantaraman, 1990). Kesannya telah menyebabkan kadar berkesatuan (density) adalah kurang meskipun bilangan kesatuan sekerja yang didaftarkan telah bertambah (Ganesan, et al., 2014). Dengan itu telah mengurangkan kuasa tawar-menawar (bargaining power) bagi kesatuan sekerja di Malaysia dan akhirnya turut mempengaruhi peranan kesatuan dalam aspek pembuatan keputusan di peringkat Parlimen. Dengan itu, dapat dikatakan bahawa pergerakan kesatuan sekerja di Malaysia berada pada tahap 'kurang berpengaruh' jika dibandingkan dengan beberapa negara lain (Thailand, Indonesia dan Filipina). Namun begitu, amalan berkesatuan tetap diteruskan dengan pelbagai sekatan bagi menjamin keharmonian dalam perhubungan perusahaan terutamanya untuk menjamin kemasukan pelaburan asing (Kuruvilla \& Erickson, 2002). Kesannya telah mempengaruhi kelangsungan kesatuan sekerja yang terus wujud seperti yang berlaku di negara-negara lain (Ahmad \& Bustami, 2017a).

Berdasarkan kenyataan tersebut, dapat disimpulkan berkaitan hubungan antara dasar pemerintah terhadap kelangsungan kesatuan sekerja. Menurut pandangan Marxist, hubungan tersebut bersifat berat sebelah iaitu pemerintah lebih cenderung untuk menyebelahi golongan pemodal (majikan) disebabkan kepentingan bersifat timbal balik antara pemerintah dan pemodal (Jomo \& Todd, 1994; Said, 1992). Kajian dalam konteks Malaysia mendapati bahawa hubungan berat sebelah telah berlaku terutamanya pada era perindustrian ketika pimpinan tertinggi negara diterajui oleh Tun Dr. Mahathir Mohammad. Antara dasar yang berkaitan ialah Dasar Pandang ke Timur (1982) dan Dasar Persyarikatan Malaysia (1983). Kedua-dua dasar tersebut memberi kesan kepada kesatuan sekerja terutamanya pengenalan konsep 'kesatuan dalaman' dan kerjasama antara sektor swasta dan sektor awam.

Contoh yang diberikan di atas merupakan salah satu impak dasar pembangunan negara terhadap pergerakan kesatuan sekerja di Malaysia. Sehubungan dengan itu, terdapat pelbagai kajian telah dilakukan bagi menganalisis hubungan tersebut antaranya adalah berkaitan keberkesanan kesatuan sekerja yang dikaitkan kepada beberapa faktor seperti keyakinan di kalangan para pekerja, penerimaan pihak majikan (Rose \& Kumar, 2011) dan dasar pemerintah (Jomo, 2014).

Lanjutan daripada itu, dapat disimpulkan bahawa kajian berkaitan pengaruh corak kepimpinan tertinggi negara yang menggabungkan enam orang pemimpin (Perdana Menteri) masih kurang dilakukan. Kajian-kajian tersebut menimbulkan persoalan berkaitan hubungan 
antara dasar perburuhan dan corak kepimpinan tertinggi negara yang seterusnya akan memberi kesan terhadap perkembangan kesatuan sekerja. Disebabkan kekurangan tersebut, kajian ini dilakukan bagi menilai kesan perubahan kepimpinan terhadap dasar perburuhan yang seterusnya turut memberi kesan kepada perkembangan kesatuan sekerja.

Oleh itu, objektif kajian ini adalah untuk menjelaskan berkaitan perubahan dasar perburuhan di Malaysia yang dibentuk berdasarkan corak kepimpinan tertinggi negara dan seterusnya akan turut mempengaruhi corak perhubungan perusahaan. Tujuan utama pembentukan dasar tersebut adalah untuk menyokong proses pembangunan negara yang baru merdeka yang telah berubah dari negara baru merdeka kepada ekonomi berasaskan pertanian, diikuti dasar perindustrian dan akhirnya menuju ke arah negara berpendapatan tinggi menjelang tahun 2020. Kesinambungan pembangunan itu turut dipengaruhi oleh dasar perburuhan dan akhirnya akan mempengaruhi keharmonian hubungan industri.

\subsection{Kaedah Kajian}

Kertas kerja ini dikembangkan berdasarkan analisis terhadap pelbagai wacana berkaitan tiga tema besar iaitu kesatuan sekerja, hubungan industri dan pemimpin tertinggi negara. Tumpuan diberikan terhadap elemen hubungan industri iaitu berkaitan kepentingan kesatuan sekerja dan pengaruh dasar pemerintah.

\subsection{Analisis Literatur}

Analisis pada bahagian ini adalah untuk menjelaskan konsep utama iaitu kepimpinan tertinggi negara, dasar perburuhan dan kesatuan sekerja dalam konteks hubungan industri. Konsep 'Kepimpinan Tertinggi Negara' merujuk kepada jawatan Perdana Menteri iaitu individu yang bertanggungjawab untuk mengetuai sistem pentadbiran sesebuah negara. Oleh itu akan menilai peranan seorang pemimpin dalam menjalankan kepimpinannya dan peranan seorang Perdana Menteri dalam menguruskan hal ehwal kenegaraan seperti yang dinyatakan oleh Mohammed, (2005) bahawa:

"A prime minister is the leader of the whole nation. In general, there are many roles expected of him. At all time, he is expected to guide the people by setting himself as the role model. Is he a man of his words especially when it comes to realising the party's election manifesto? Is he able to initiate the necessary drive for the people to help him achieve what he wants for the good of the country? Does he has the ability to balance that delicate matters concerning issues which are deemed to be seen as highly sensitive in a multi-ethnic society like in Malaysia?

Berdasarkan penjelasan tersebut, konsep kepimpinan yang digunakan dalam kertas kerja ini adalah untuk mengaitkan corak/sikap Perdana Menteri terhadap dasar pembangunan dan kaitannya dengan dasar perburuhan di Malaysia. Secara umumnya, 'sesuatu dasar' merupakan kenyataan mengenai hasrat pihak kerajaan untuk mencapai sesuatu maksud. Dengan kata lain, 
satu pengisytiharan mengenai hasrat dan ideologi kerajaan yang dibuat dari masa ke semasa khususnya untuk mencapai objektif dan menyelesaikan isu-isu berkaitan. Dasar-dasar yang digubal adalah bersifat menyeluruh dan merangkumi pelbagai aspek termasuklah ekonomi, politik, sosial, agama, pendidikan dan lain-lain lagi. Setiap dasar yang digubal oleh pihak kerajaan telah mengambil kira kepentingan awam serta kebajikan awam (INTAN, 1994)

Dasar-dasar kerajaan digubal dan dilaksanakan mengikut kesesuaian ciri-ciri dan keperluan semasa negara. Dasar kerajaan dapat juga difahami sebagai rancangan tindakan yang telah dipersetujui secara rasmi sebagai asas untuk membuat atau melaksanakan sesuatu keputusan kerajaan. Dalam konteks Malaysia, terdapat pelbagai dasar yang telah digubal dan dilaksanakan. Antara dasar-dasar kerajaan yang penting termasuklah Dasar Ekonomi Baru yang kemudiannya digantikan oleh Dasar Pembangunan Nasional, Dasar Perindustrian Negara, Dasar Pertanian Negara, Dasar Persyarikatan Negara, Dasar Pendidikan Negara, Dasar Buruh Negara dan Dasar Penerapan Nilai-Nilai Islam dalam Pentadbiran (Institut Tadbiran Awam Negara (INTAN), 1994).

Tujuan utama melaksanakan dasar-dasar tersebut adalah untuk meningkatkan kecekapan dan produktiviti, mengurangkan kos pengurusan, mengatasi masalah-masalah yang timbul, meletakkan asas pentadbiran negara serta organisasi. Tiga jenis dasar utama kerajaan adalah merangkumi Dasar-Dasar Ekonomi, Sosial dan Etika Kerja serta Dasar-Dasar Luar.

Secara umumnya, terdapat fasa-fasa tertentu dalam membincangkan dasar-dasar kerajaan sebagaimana yang dinyatakan oleh Institut Tadbiran Awam Negara (INTAN) (1994). Fasa pertama adalah pada zaman penjajahan British. Walau bagaimanapun, penglibatan pihak kerajaan British dalam penggubalan serta pelaksanaan polisi hanya pada kadar yang minimal kerana fokus mereka adalah untuk mengaut hasil semaksimum untuk dibawa ke negara asal. Namun demikian, dasar pecah dan perintah yang dilaksanakan oleh kerajaan British pada waktu tersebut telah memberikan impak yang sangat besar kepada masyarakat terutamanya dari aspek politik serta sosioekonomi.

Fasa kedua pula adalah ketika era Malayan Union yang bermula pada tahun 1946 sehingga 1957. Pelaksanaan dasar pada waktu tersebut lebih menjurus ke arah untuk mencapai kemerdekaan negara. Pemimpin-pemimpin daripada pelbagai latar belakang telah sama-sama berusaha untuk memastikan asas pembinaan negara dapat dicapai. Manakala fasa ketiga pula meliputi tempoh masa bermula pada awal kemerdekaan sehingga 13 Mei 1969. Satu rusuhan kaum telah berlaku akibat daripada ketidakseimbangan ekonomi antara kaum-kaum utama di Semenanjung Malaysia. Rentetan daripada peristiwa tersebut, pihak kerajaan telah menggubal satu dasar yang dinamakan Dasar Ekonomi Baru yang telah dilaksanakan dalam tempoh fasa keempat bermula pada tahun 1971 sehingga 1990. Bermula pada tahun 1991 hingga 2000, pihak kerajaan Malaysia telah melancarkan Dasar Pembangunan Nasional bagi menggantikan Dasar Ekonomi Baru. (INTAN, 1994). 
Seiring dengan peredaran masa serta pelbagai perubahan yang berlaku dalam konteks ekonomi, politik dan sosial serta perubahan persekitaran, maka pihak kerajaan terus proaktif untuk memperkenalkan pelbagai dasar untuk terus memacu negara ke arah yang lebih baik di masa hadapan. Dasar-dasar yang diperkenalkan oleh pemimpin-pemimpin negara bukan sahaja memberi impak kepada negara dan rakyat, namun turut mempengaruhi sistem hubungan industri dan pekerjaan di Malaysia. Dasar Pandang Ke Timur sebagai contohnya telah membawa perubahan terhadap pergerakan kesatuan sekerja di negara ini. Pengenalan kesatuan sekerja dalaman adalah kesan daripada pengenalan Dasar Pandang Ke Timur. Begitu juga dengan pengenalan Dasar Perindustrian Negara yang telah membuka ruang kepada para pekerja untuk memperolehi latihan dan pembangunan seiring dengan keperluan perindustrian negara. Terkini, Dasar Gaji Minimum yang telah dilaksanakan oleh pihak kerajaan telah memberi peluang yang lebih baik kepada rakyat untuk menikmati kehidupan yang lebih baik seiring dengan peningkatan kos sara hidup yang semakin tinggi.

Konsep terakhir ialah kesatuan sekerja yang merupakan sebuah organisasi yang menggabungkan para pekerja bagi mencapai satu matlamat yang sama. Menurut Salamon (1998), kesatuan sekerja digambarkan sebagai organisasi pekerja yang ditubuhkan untuk memperbaiki status pembayaran dan kondisi pekerjaan dalam kalangan ahli-ahlinya, kesatuan sekerja juga merupakan persatuan pekerja yang berusaha melalui perundingan kolektif untuk memperbaiki kondisi kerja, ekonomi dan kedudukan sosial dan berusaha menggunakan kuasa perundingan kolektif dalam memperbaiki upah dan kondisi pekerjaan dalam kalangan ahli.

Selain itu, dari perspektif perundangan pula kesatuan sekerja merangkumi kesatuan pekerja atau kesatuan sekerja majikan dan didefinisikan dalam seksyen 2 (1) Akta Kesatuan Sekerja 1959 yang bermaksud “...apa-apa pertubuhan atau gabungan pekerja-pekerja atau majikan-majikan, yang menjadi pekerja di mana tempat pekerjanya adalah di Malaysia Barat, Sabah atau Sarawak mengikut mana-mana yang berkenaan, iaitu i) dalam mana-mana pertubuhan, tred, pekerjaan atau industri yang tertentu atau dalam apa-apa industri yang serupa; ii) sama ada secara sementara atau tetap; dan iii) yang mempunyai antara tujuan-tujuannya satu atau lebih daripada tujuan-tujuan yang tertentu (Akta Kesatuan Sekerja, 1959).

Oleh itu, berdasarkan pengertian kesatuan sekerja tersebut, sekumpulan pekerja hanya boleh menubuhkan kesatuan sekerja berdasarkan tempat mereka bekerja sama ada di Malaysia Barat, Sabah ataupun di Sarawak. Sekumpulan pekerja juga tidak boleh menubuhkan sebuah kesatuan sekerja yang dianggotai oleh pekerja yang bekerja di tempat yang berlainan seperti di Malaysia Barat, Sabah atau Sarawak.

Menurut Tan Kwang How (2011) kesatuan sekerja merupakan satu sistem sosial yang dipengaruhi oleh persekitaran dalamam dan luar organisasi. Situasi ini menunjukkan perubahan dasar kepimpinan sangat mempengaruhi corak kesatuan sekerja. Sungguhpun begitu matlamat kesatuan sekerja adalah jelas di mana kesatuan sekerja ini berfungsi dalam memperjuangkan hak-hak kesatuan sekerja yang berhubung kait dengan terma dan kondisi pekerjaan, kebajikan 
pekerja dan jaminan pekerjaan. Sehubungan dengan matlamat kesatuan sekerja, penubuhannya menerima impak daripada kestabilan pemerintahan negara, polisi kerajaan, kestabilan ekonomi yang meliputi kadar inflasi, kadar pengangguran dan kukuhnya nilai kewangan syarikat.

Mohamed dan Chen (2011) dan Kee Mohd Yussof et al., (2015) menyatakan kesatuan sekerja antara lain adalah berperanan merundingkan terma dan kondisi pekerjaan melalui perundingan kolektif bersama pihak majikan, menasihati pekerja dan majikan berkaitan polisi buruh dalam organisasi, menyelesaikan aduan ketidakadilan yang dialami oleh pekerja, menganjurkan piket yang munasabah, mewakili dan melindungi pekerja bersesuaian dengan kehendak undang-undang perburuhan di Malaysia. Berdasarkan penjelasan tersebut, penjelasan seterusnya adalah berkaitan dapatan kajian iaitu hubungan antara corak kepimpinan dan dasar perburuhan serta kesannya terhadap pergerakan kesatuan sekerja di Malaysia.

\subsection{Dapatan Kajian}

Pengaruh corak kepimpinan terhadap pembentukan dasar perburuhan (pembangunan) negara telah memberi kesan terhadap perkembangan kesatuan sekerja di Malaysia. Hubungan ini ditunjukkan pada Jadual 1 yang menunjukkan perbezaan corak kepimpinan kesemua Perdana Menteri yang telah mentadbir negara sejak tahun 1957. Kajian ini mengesahkan dapatan berkaitan pengaruh yang signifikan antara corak kepimpinan dan dasar perburuhan yang diasaskan kepada matlamat pembangunan masing-masing. Berdasarkan kepada hubungan tersebut, penjelasan pada bahagian ini akan dimulakan dengan dapatan berkaitan corak kepimpinan Perdana Menteri dan diikuti dengan analisis terhadap pembentukan dasar dan kesannya terhadap kesatuan sekerja berdasarkan empat fasa. Perkembangan pada fasa pertama (1920-1957) ialah sebelum kemerdekaan, diikuti pada fasa kedua (1957-1970) iaitu zaman awal kemerdekaan, kemudian pada fasa ketiga (1971-2000) iaitu fasa perindustrian dan yang terakhir adalah pada fasa keempat (2001-2020) iaitu era milenium baru.

Jadual 1: Hubungan Kepimpinan, Dasar Buruh dan Kesatuan Sekerja di Malaysia

\begin{tabular}{|l|l|l|l|}
\hline Perdana Menteri & Corak Kepimpinan & Dasar Buruh & Kesatuan Sekerja \\
\hline $\begin{array}{l}\text { Tunku Abd. } \\
\text { Rahman }\end{array}$ & $\begin{array}{l}\text { Bapak Kemerdekaan } \\
\text { Kemahiran } \\
\text { Diplomatik }\end{array}$ & $\begin{array}{l}\text { Kestabilan dan } \\
\text { ketenteraman negara }\end{array}$ & Kuat / Berpengaruh \\
\hline Tun Abdul Razak & $\begin{array}{l}\text { Visionary } \\
\text { Great Emphaty }\end{array}$ & $\begin{array}{l}\text { Pertanian dan } \\
\text { perpaduan kaum }\end{array}$ & Kuat /Berpengaruh \\
\hline Tun Hussein Onn & $\begin{array}{l}\text { Meneruskan agenda } \\
\text { Tun Razak }\end{array}$ & $\begin{array}{l}\text { Kestabilan dan } \\
\text { Perpaduan kaum }\end{array}$ & Peralihan \\
\hline Tun Dr. Mahathir & iconoclastic leader & $\begin{array}{l}\text { Perindustrian dan } \\
\text { Wawasan 2020 }\end{array}$ & $\begin{array}{l}\text { Lemah / kurang } \\
\text { berpengaruh }\end{array}$ \\
\hline Tun Abdullah & humility and concern & Ketelusan dan & Lemah / kurang \\
\hline
\end{tabular}


Journal of Borneo Social Transformation Studies (JOBSTS), Vol. 5. No. 1, 2019

ISSN 2462-2095

Universiti Malaysia Sabah

\begin{tabular}{|l|l|l|ll|}
\hline & for people & Integriti & berpengaruh & \\
\hline Dato Seri Najib & Program Transformasi & $\begin{array}{l}\text { Konsep 1 Malaysia } \\
\text { dan Transformasi }\end{array}$ & $\begin{array}{l}\text { Lemah / kurang } \\
\text { berpengaruh }\end{array}$ & \\
\hline Tun Dr. Mahathir & Malaysia Baharu & Manifesto Harapan & Peralihan & \\
\hline
\end{tabular}

Sumber: Disusun berdasarkan kajian lepas

\subsection{Corak kepimpinan Perdana Menteri}

Jadual 1 menunjukkan perbezaan corak kepimpinan yang diberikan terhadap enam orang Perdana Menteri Malaysia dan kaitannya dengan dasar perburuhan. Meskipun terdapat perbezaan kepimpinan, perbezaan tersebut dianggap sesuatu yang positif disebabkan kemampuannya menghasilkan suasana politik yang aman sejak negara mencapai kemerdekaan pada tahun 1957. Sehubungan dengan itu, dasar-dasar pembangunan yang telah dirancang turut menggunakan pendekatan yang sama iaitu kesinambungan antara seorang perdana menteri dan penggantinya yang baharu. Kesinambungan tersebut menunjukkan sistem politik di Malaysia seperti yang dijelaskan oleh Mohamed (2005):

"The success story of prime ministership in Malaysia testifies that the Malaysian political system i.e. in a Malay-Muslim polity needs a continuously strong alliance political organisation and culture that are sound and stable. It is true that all the prime ministers in Malaysia have been so successful."

Amalan perkongsian kuasa melalui Parti Perikatan yang menyatukan pelbagai kaum di Malaysia menjadi asas kepada kestabilan sistem pentadbiran. Sistem tersebut telah bermula pada zaman pemerintahan Tunku Abdul Rahman yang merupakan Perdana Menteri yang pertama. Corak kepimpinan Tunku banyak dipengaruhi oleh sikapnya yang cenderung kepada konsep 'diplomasi'. Corak kepimpinan ini menurut Mohamed (2005) adalah seperti berikut:

"The late Tunku has been successful in achieving independent despite stern actions and challenges from every corner. As already have been indicated by a few scenarios, apart from being an Anglophile, Tunku's diplomatic skills helped reassure the British that granting independence to Malaya was the right thing to do."

Pendekatan yang sama telah diteruskan oleh Tun Abdul Razak yang terkenal dengan sikapnya yang bersifat berpandangan jauh (visionary) dan memiliki sifat suka mengambil berat terhadap orang lain. Manakala sikap Perdana Menteri ketiga pula iaitu Tun Hussein Onn adalah untuk meneruskan agenda pembangunan yang telah dilaksanakan sepanjang pentadbiran Tun Abdul Razak. Kesinambungan ini seperti yang dijelaskan oleh Mohamed (2005) sebagai suatu yang tepat. Beliau menjelaskan bahawa:

"Tun Razak - a visionary and and had great empathy towards the people - has succeeded in transforming the nation by putting into place a major economic and societal reform. Tun Hussein Onn, the third premier, made no mistake in continuing the agenda that his predecessor had put into place." 
Perkembangan seterusnya adalah zaman pentadbiran Tun Dr. Mahathir yang telah mempergiatkan proses perindustrian di Malaysia. Terdapat pelbagai dasar telah dibentuk pada tempoh ini yang dikaitkan dengan sikap Tun Mahathir yang berpandangan jauh dan bersifat 'man of action' seperti yang dinyatakan oleh Mohamed (2005):

"The twenty-two years of Tun Mahathir's administration saw the passing of a decade of the Tun Razak's New Economic Policy. He was seen as an iconoclastic leader who challenged prevailing ideas and beliefs. He is also remembered for his uniqueness, for he was both a visionary and a man of action."

Perubahan yang dilakukan pada era perindustrian telah meletakkan Malaysia dalam kedudukan yang tersendiri di peringkat global. Sehubungan dengan itu, perdana Menteri yang kelima iaitu Tun Abdullah telah memberi tumpuan terhadap konsep keadilan dan ketelusan dalam pentadbiran. Menurut Mohamed (2005) ciri-ciri tersebut adalah:

"Malaysia at the moment is under the leadership of Datuk Seri Abdullah Badawi. Known for his humility and concern for people, Abdullah certainly has a lot of opportunities to rise to the occasions and as the Deputy Prime Minister has said, "with the increasing pressures of globalisation, stronger demands for a more open and transparent economy and business environment, Abdullah's rise to the top was timely".

Kesinambungan corak pentadbiran Perdana Menteri terus dilaksanakan oleh Datuk Seri Najib dengan memberi tumpuan terhadap gabungan antara perpaduan dan pembangunan ekonomi. Sasaran ini dijelmakan melalui program Transformasi Negara dan pengenalan konsep 1 Malaysia yang telah mendasari pelbagai program pembangunan dan dasar pembangunan negara.

Perbezaan corak kepimpinan ini telah memberi satu kekuatan kepada kestabilan politik dan seterusnya menyumbang kepada proses pembangunan ekonomi negara. Pada masa yang sama corak tersebut turut mempengaruhi kelangsungan kesatuan sekerja meskipun dalam tempoh tertentu terdapat pemimpin yang cenderung untuk menyekat kebebasan kesatuan sekerja. Dengan itu, bahagian seterusnya adalah penjelasan berkaitan perkembangan tersebut berdasarkan fasa yang berlainan.

\subsection{Perkembangan Fasa Pertama (1920-1957)}

Perkembangan pada fasa ini merupakan asas pembentukan sistem perhubungan perusahaan di Malaysia dan telah direncanakan oleh kuasa kolonial. Corak pentadbiran British adalah untuk menyokong perkembangan ekonomi kapitalis dengan menumpukan kepada sektor pertama iaitu perlombongan Biji Timah dan Perladangan Getah. Bagi mencapai matlamat ekonomi kapitalis, dasar pengambilan buruh dari luar telah dilaksanakan bagi mengatasi kekurangan buruh di Tanah Melayu (Gamba, 1962). Dengan itu, pengambilan buruh telah dilakukan dari negara China dan India. Pemilihan buruh China adalah kesinambungan kepada kewujudan pemodal China yang sedia ada di Tanah Melayu manakala pengambilan Buruh dari 
India disebabkan penguasaan British di negara tersebut. Kesannya telah menyebabkan pengeluaran telah dapat ditingkatkan dengan mengamalkan dasar pengambilan buruh murah yang dapat menjimatkan kos (Fong, 1999).

Disebabkan dasar-dasar tersebut, hak dan kebajikan buruh-buruh Imigran ini telah diabaikan dan mendapat layanan yang teruk dari golongan kapitalis (Al-Atas, 1988). Kesan tekanan yang berterusan telah menyumbang kepada beberapa siri penentangan oleh buruh imigran dan menjadi asas kepada pembentukan kesatuan sekerja di Tanah Melayu sebagaimana yang dijelaskan oleh (Wad, 2001:5) bahawa:

"The legacy of trade unionism dates back to the formation of centralised trade unionism during British colonialism, based on the development of Chinese and Communist controlled labour organisations during the 1930s and 1940s. The trade unions were organised as general unions, based on geographical criteria across trades and industries and united under a central leadership. The general union movement became illegal in 1947-48 clashing with the returning British colonial authorities, who tried to instigate a British reformist labour movement composed of a British-like labour party and sector-wide unions (trade, industry, occupation)."

Sehubungan dengan itu, gerakan kesatuan sekerja telah mencapai tahap kemajuan apabila pelbagai kesatuan telah bergabung di bawah satu kesatuan iaitu General Labour Union dan kemudiannya telah membentuk Malayan General Labour Union (MGLU). Namun begitu, disebabkan pengaruh dari Parti Komunis Malaya (PKM), dasar pentadbiran British telah memperkenalkan kesatuan yang bersifat sederhana dan bebas dari pengaruh PKM dengan menubuhkan Malayan Trade Union Congress (MTUC). Dasar ini adalah untuk menyokong sifat demokratik kerajaan British dan memberi kebebasan kepada pekerja untuk berkesatuan dengan kawalan dari pemerintah sehingga Tanah Melayu mencapai kemerdekaan pada tahun 1957 (Stenson, 1977).

Senario perburuhan seperti yang dijelaskan sebelum ini dapat diringkaskan seperti yang ditunjukkan pada Jadual 2 iaitu hubungan corak pentadbiran British yang bersifat corporatism berasaskan semangat 'kapitalisme'. Corak tersebut telah mempengaruhi pelbagai dasar berkaitan pengambilan buruh yang akhirnya turut memberi kesan kepada pembentukan gerakan buruh di Tanah Melayu. Gerakan ini kemudiannya digunakan oleh Parti Komunis Malaya sebagai salah satu strategi bagi mencapai matlamat mereka untuk menyebarkan ideologi sosialis di Tanah Melayu.

Jadual 2: Perkembangan Fasa 1 (1920-1957)

\begin{tabular}{|l|l|l|l|}
\hline Pemerintah & $\begin{array}{l}\text { Corak } \\
\text { Kepimpinan }\end{array}$ & Dasar Buruh & Kesatuan Sekerja \\
\hline $\begin{array}{l}\text { Kolonial } \\
\text { British }\end{array}$ & Corporatism & Buruh Imigran & $\begin{array}{l}\text { Bermula di kalangan } \\
\text { buruh Cina }\end{array}$ \\
\cline { 2 - 4 } & Kapitalism & Lebihan Buruh & Pengaruh PKM \\
\hline
\end{tabular}


Journal of Borneo Social Transformation Studies (JOBSTS), Vol. 5. No. 1, 2019

ISSN 2462-2095

Universiti Malaysia Sabah

\begin{tabular}{|l|l|l|l|}
\hline \multirow{2}{*}{} & Kebajikan buruh & $\begin{array}{l}\text { Kemeseletan } \\
\text { Ekonomi }\end{array}$ \\
\cline { 2 - 3 } & & Penghapusan PKM & Perang Dunia Ke-2 \\
\hline
\end{tabular}

Sumber: Disusun berdasarkan beberapa kajian utama: Gamba (1962), Stenson (1977), Said (1992), Jomo dan Todd (1994) dan Fong (1999).

Bagi mengawal pengaruh tersebut, kerajaan British telah memperkenalkan Undang-Undang Darurat pada tahun 1948 dan menyekat kebebasan gerakan kesatuan sekerja dengan memperkenalkan Ordinan Buruh yang telah digubal pada tahun 1940 (Said, 1992). Kesannya telah menyebabkan kesatuan sekerja telah berubah dan lebih bersifat kurang menentang berbanding sebelum ini. Asas pembentukan ini telah dilanjutkan selepas negara mencapai kemerdekaan yang menunjukkan pengaruh corak kepimpinan Tunku Abdul Rahman yang diasaskan kepada pendekatan Diplomasi. Kesinambungan tersebut telah dilanjutkan oleh Tun Abdul Razak yang lebih dikenali dengan pelbagai dasar untuk meningkatkan perpaduan di kalangan penduduk Malaysia kesan peristiwa Rusuhan Kaum, 1969 (Idrus, 2001).

\subsection{Perkembangan Fasa Kedua (1957- 1970)}

Perkembangan pada fasa kedua menunjukkan kesinambungan dasar pentadbiran British yang telah diteruskan oleh Tunku Abdul Rahman sebagai sebuah negara yang baru merdeka. Tunku Abdul Rahman merupakan perdana menteri Malaysia yang pertama dan zaman pemerintahan beliau senario hubungan industri boleh dibahagikan kepada dua peringkat. Peringkat pertama pentadbirannya bermula pada tahun 1957 hingga 1965 manakala peringkat kedua pula ialah pada tahun 1966 sehingga tahun 1969.

Perkembangan pada fasa yang pertama iaitu sepanjang tempoh masa tahun 1940 sehingga tahun 1965, sistem voluntarism diamalkan dalam hubungan industri di Malaysia. Semasa penaklukan British dan pembentukan Ordinan Kesatuan Sekerja dalam tahun 1940-an, corak hubungan industri adalah berdasarkan model Sistem British kecuali perkara berkaitan mewajibkan pendaftaran kesatuan sekerja.

Sehubungan dengan itu, dapat ditegaskan bahawa sepanjang tempoh antara tahun 19401965 ciri-ciri voluntarism dalam hubungan industri wujud di Tanah Melayu (kemudian Persekutuan dan akhirnya Malaysia pada tahun 1963). Namun sistem hubungan industri pada masa itu adalah berdasarkan model sistem perburuhan British. Ciri-ciri hubungan industri yang berbentuk kesukarelaan (voluntarism) telah memberikan kebebasan kepada pekerja untuk menyertai mana-mana kesatuan sekerja tanpa halangan dari segi skop pekerjaan dan majikan. Walaupun pada masa itu ordinan kesatuan sekerja mula dikuatkuasakan tetapi pekerja masih boleh menganggotai mana-mana kesatuan walaupun berbeza sektor dan majikan. Maka pada ketika itu ramai pekerja bergabung dan menganggotai kesatuan sekerja seperti General Labour Union (GLU). 
Sistem voluntarism ini menunjukkan senario perburuhan yang amat sukar, di mana pekerja mempunyai kebebasan sepenuhnya dalam menganggotai kesatuan sekerja dan tidak menggalakkan pihak kerajaan untuk campur tangan jika berlaku pertikaian dalam hubungan majikan dan pekerja. Situasi ini menyebabkan pergerakan kesatuan sekerja dan mogok tidak dapat dikawal oleh pihak kerajaan, malah majikan pada masa itu tidak dapat menghalang pengaruh komunis yang meresap masuk dalam perjuangan para pekerja. Walaupun pada masa itu kesatuan sekerja boleh menuntut terma dan kondisi pekerjaan daripada pihak majikan yang juga terdiri daripada penjajah atau orang British melalui, namun kerajaan British menggalakkan kesatuan menyelesaikan pertikaian industri tanpa campur tangan kerajaan. Oleh itu sistem Voluntarism ini menunjukkan kerajaan hanya mempunyai kuasa yang minima dan tidak boleh campur tangan dalam pertikaian di antara majikan dan kesatuan sekerja. Kerajaan sebagai pihak ketiga seolah-olah boneka yang tidak mempunyai kuasa mutlak untuk campur tangan dalam pertikaian yang berlaku antara majikan dan pekerja (Anantaraman, 1997).

Selepas perang dunia kedua pada tahun 1946, Mahkamah Industri ditubuhkan. Industrial Court atau Mahkamah Industri ini hanya berfungsi untuk mengadakan proses timbang tara atas permintaan pihak yang bertikai. Ini bermaksud pihak kerajaan hanya boleh campur tangan apabila pihak majikan atau kesatuan sekerja mempelawa mereka untuk menyelesaikan pertikaian yang berlaku. Pada masa ini pendaftaran kesatuan sekerja mula dilakukan oleh pihak kerajaan namun kerajaan tidak boleh campur tangan dan kesatuan sekerja bebas mengadakan pertikaian industri (Anantaraman, 1997; Jomo \& Todd, 1996). Perundingan kolektif mula diperkenalkan namun ia bersifat Free Collective Bargaining dan perundingan kolektif amat sukar dilaksanakan. Ini kerana skop pekerjaan dan majikan dalam keanggotaan kesatuan sekerja yang pelbagai dan menyebabkan perjuangan menjadi tidak terarah. Pada masa itu mogok, ketidakpuasan hati terhadap terma dan kondisi pekerjaan menunjukkan situasi yang membimbangkan. Pada tahun 1962 dan 1964, peristiwa mogok semakin meningkat. Negara Malaysia menjadi tidak stabil dan harmoni dengan pergerakan buruh yang tidak terkawal. Situasi ini telah membawa perubahan kepada corak hubungan industri yang membentuk peringkat kedua dalam pentadbiran Perdana Menteri yang pertama.

\section{Peringkat kedua pentadbiran Tunku Abdul Rahman pada tahun 1965-1969}

Pada peringkat ini pihak kerajaan telah mengubah sistem hubungan industri daripada sistem voluntarism (sukarela) kepada sistem compulsory (wajib). Bertitik tolak daripada peristiwa konfrontasi Indonesia-Malaysia yang membawa kepada pembentukan Malaysia, Sabah dan Sarawak pada September 1963. Ketidakstabilan yang berlaku pada masa itu menyebabkan kerajaan mengambil kesempatan mengubah sistem voluntary kepada compulsory. Sistem ini menekankan kewajipan pihak kerajaan untuk masuk campur dalam pertikaian yang berlaku di antara majikan dan kerajaan. Menurut Said (1992) kewajipan kerajaan dalam rundingan secara sukarela telah digantikan dengan rundingan wajib bagi menyelesaikan pertikaian. Pada awalnya, mewajibkan campurtangan kerajaan ini adalah bertujuan untuk menghadapi keadaan Darurat 
tetapi apabila pihak kerajaan melihat langkah ini berkesan mengurangkan pertikaian maka campur tangan kerajaan ini dimasukkan ke dalam Akta (pindaan) Hubungan Perusahaan.

Hasil daripada perubahan sistem ini, organisasi kesatuan sekerja lebih teratur dan mudah dikawal oleh pihak majikan. Essential Regulation (1965) turut dibentuk yang menghalang pertikaian dalam sektor awam. Sehubungan dengan itu, Industrial Arbitration Tribunal ditubuhkan untuk mengadili pertikaian yang berlaku dan menteri di Jabatan Buruh dibenarkan untuk campur tangan dalam pertikaian industri. Perubahan sistem ini meletakkan kerajaan sebagai institusi penting dalam menyelesaikan pertikaian industri. Penguatkuasaan Ordinan Kesatuan Sekerja 1959 telah melemahkan pengaruh PKM.

Perubahan sistem ini berlaku kerana sistem voluntary tidak berupaya membentuk keharmonian hubungan industri malah menyebabkan pertikaian yang tidak terkawal antara majikan dan pekerja. Tambahan pula pada ketika itu Parti Komunis Malaya (PKM) telah menyebarkan ideologinya dan mengganggu gugat pergerakan kesatuan sekerja. Kesukarelaan (voluntarism) juga membenarkan pekerja menganggotai kesatuan sekerja seperti General Labour Union (GLU) yang terdiri daripada pelbagai bidang pekerjaan. Situasi itu seterusnya menyebabkan perjuangan kesatuan sekerja menjadi tidak terarah dan pertikaian seperti mogok sukar dikawal. Sifat kesatuan sekerja adalah lebih agresif terhadap pemerintah dan bergerak secara militan atau ketenteraan. GLU digunakan oleh PKM untuk mencapai matlamatnya dalam membentuk Republik Malaya. Menurut Said (1992), GLU merupakan suatu peristiwa penting dalam perkembangan organisasi buruh di Malaysia walaupun persatuan ini tidak diterima untuk didaftarkan secara sah oleh pentadbiran tentera Inggeris (BPA).

Anantaraman (1997) menyatakan compulsory itu merujuk kepada campur tangan pihak kerajaan ke atas pertikaian yang tidak dapat diselesaikan bersama pihak majikan walaupun pihak yang bertikai tidak meminta campur tangan tersebut. Dengan mengamalkan sistem ini kes mogok dan pertikaian berkurangan dan kerajaan melihat sistem ini amat berkesan dalam memperbaiki keadaan ekonomi negara pada masa itu. Hakikatnya, pada zaman pemerintahan Tunku Abdul Rahman, beliau menggalakkan penubuhan kesatuan sekerja. Kerajaan pada masa itu menghargai kesatuan sekerja kerana ia dianggap sebagai satu pertubuhan yang turut membantu dalam proses mencapai kemerdekaan. Sehubungan dengan itu satu Department of Labour \& Industrial Relation telah dibentuk. Pada masa yang sama, penguatkuasaan terhadap Ordinan Kesatuan Sekerja dan Ordinan Hubungan Industri dilakukan dan digubal dari masa ke semasa. Sebelum ordinan tersebut, dikuatkuasakan pekerja boleh menganggotai mana-mana kesatuan walaupun berbeza sektor dan majikan, namun selepas penguatkuasaan Ordinan Kesatuan Sekerja, keanggotaan kesatuan sekerja lebih khusus dan teratur mengikut bentuk pekerjaan tertentu.

Pada zaman ini kawalan ketat untuk mendaftarkan kesatuan sekerja telah bermula. Pada asalnya pendaftaran yang ketat terhadap keanggotaan kesatuan sekerja adalah untuk mengurangkan pengaruh Parti Komunis Malaya (PKM) dan organisasi buruh yang bercorak 
militant atau ketenteraan. Pendaftaran kesatuan sekerja yang ketat telah membentuk kesatuan sekerja yang lebih tersusun dan pentadbiran kesatuan yang lebih sistematik dapat dilakukan. Fungsi MTUC dan CUEPACS dikemaskinikan dan berperanan sebagai "moderator" terhadap pergerakan buruh dan majikan.

Pada tahun 1960-an kerajaan telah memberi fokus kepada usaha menguatkuasakan undang-undang berkaitan buruh. Kerajaan memberi fokus kepada pelabur asing dan modal untuk memulihkan keadaan ekonomi di Malaysia. Pada masa yang sama kesedaran mula timbul dalam kalangan kesatuan sekerja dan mereka mula memberi fokus terhadap usaha memperbaiki Bread and Butter issues dan perundingan kolektif mula dilaksanakan oleh majikan dan pekerja. Pada zaman pentadbiran Perdana Menteri yang pertama ini telah menyaksikan perubahan daripada free collective bargaining kepada perundingan kolektif yang lebih fokus kepada keanggotaan kesatuan sekerja tertentu.

\section{Pentadbiran Tun Abdul Razak (Mei 1969-1976)}

Perdana Menteri kedua iaitu Tun Abdul Razak mengambil alih tampuk pemerintahan, namun sistem compulsory yang mewajibkan campur tangan kerajaan masih diteruskan (Anantaraman, 1997). Walau bagaimanapun pemimpin ini menghadapi cabaran dalam memulihkan keadaan ekonomi Tanah Melayu dan berlaku komplikasi antara etnik yang turut mencorakkan sistem hubungan industri pada masa itu (Rowley \& Bhopal, n.d.). Zaman pemerintahan beliau telah melakukan perubahan yang ketara dalam ekonomi di Malaysia daripada ekonomi berdasarkan komoditi (commodity based economy) kepada ekonomi berdasarkan industri (industrial economy). Situasi ini menyebabkan satu pentadbiran buruh yang lebih ketat, namun Tun Abdul Razak cuba untuk menyeimbangkan kawalan ketat ini dengan memperkenalkan sistem akomodatif yang meletakkan situasi win-win situation antara kesatuanmajikan (Jomo \& Todd, 1996; F. Said \& Zakaria, 2002). Sistem ini dilihat lebih bersifat terbuka dan memberi layanan yang baik kepada kesatuan sekerja. Ia bertujuan untuk tidak memberi tekanan kepada pekerja yang terdiri daripada pelbagai etnik agar mengurangkan permusuhan di antara mereka. Pemimpin ini telah mengambil pengajaran daripada rusuhan kaum yang berlaku dan menilai bahawa perlunya perasaan sensitif terhadap kepentingan pelbagai etnik dalam pergerakan buruh dan tidak hanya memberi fokus kepada kemajuan ekonomi semata-mata.

Fokus utama pemimpin pada masa itu adalah mewujudkan keharmonian industri dan membawa perubahan kepada mentaliti pekerja dan kesatuan sekerja agar meninggalkan pengaruh komunis secara total. Salah satu sumbangan beliau yang masih diamalkan pada hari ini adalah sambutan Hari Pekerja pada setiap 1 Mei (Jomo \& Todd, 1996; Said \& Zakaria, 2002). Ia merupakan satu penghargaan kepada para pekerja dan menggalakkan pekerja bersatu padu walaupun berlainan bentuk pekerjaan dan khususnya untuk mengurangkan konflik berlainan etnik.

\subsection{Perkembangan Fasa Ketiga}


Journal of Borneo Social Transformation Studies (JOBSTS), Vol. 5. No. 1, 2019

ISSN 2462-2095

Universiti Malaysia Sabah

Kesinambungan pentadbiran pada fasa ini telah diteruskan oleh dua orang Perdana Menteri iaitu Tun Hussein Onn dan Tun Dr Mahathir Mohammad. Berlaku perubahan yang besar pada fasa ini disebabkan perubahan asas ekonomi negara yang lebih kepada proses perindustrian. Oleh itu dasar-dasar pembangunan telah digubal dan turut melibatkan perubahan dalam dasar dan perundangan perburuhan yang banyak ditentukan pada era pentadbiran Tun Dr. Mahathir. Dengan itu penjelasan selanjutnya akan lebih menumpukan kepada era tersebut berbanding perdana Menteri yang ketiga.

\section{Perkembangan era Tun Hussein Onn (1976-1981)}

Meskipun tempoh pentadbiran Tun Hussein hanya satu penggal, sikap dan kepimpian beliau dapat dijadikan sebagai panduan kepada pemimpin yang lain. Antara kelebihan beliau adalah dalam mengukuhkan perpaduan di kalangan masyarakat Malaysia. Dengan itu, beliau turut dikenali sebagai Bapa Perpaduan seperti yang dinyatakan dalam akbhar The Sun (2007) bahawa:

"Coming from a political dynasty that included his father, Umno founder Datuk Onn Jaafar, the third prime minister of Malaysia wore the tag of Bapa Perpaduan (Father of Unity). This label was attributed to many of his policies which were geared towards bridging the racial divide and putting an end to the pigeon-holing of the major ethnic groups into economic classes, a task he inherited from his predecessor. What remains his most profound legacy is the setting up of the National Unit Trust (Amanah Saham Nasional or ASN) scheme in 1981 where government-owned shares were transferred into bumiputra hands, and controlled by Permodalan Nasional Bhd (PNB)." (The Sun: 2007)

Selain itu, beliau juga mempunyai pandangan yang tersendiri berkaitan kuasa iaitu penekanan terhadap penggunaannya untuk kepentingan bersama:

"Hussein's words about power, which he continuously drummed into officialdom, continue to resonate for Malaysia till today: "Power is given to us not to lord it over others, not to improve our standing nor to enrich ourselves. Power must be used for the good and well-being of the people at all times. Power must always be used for the benefit of the people." (The Sun: 2007)

Berdasarkan semangat terebut, beliau terus melaksanakan dasar yang telah dibentuk sebelumnya, antaranya ialah Kod Amalan Keharmonian Perusahaan pada tahun 1975. Pada tahun tersebut, pihak Kementerian Buruh (sekarang dikenali sebagai Kementerian Sumber Manusia) bersamasama dengan pihak Malaysian Council of Employers' Organisations (sekarang dikenali sebagai Malaysian Employers Federation) dan Kongress Kesatuan Sekerja Malaysia (Malaysian Trades Union Congress) telah bersetuju untuk melancarkan satu Kod Amalan Keharmonian Industri (code of conduct of industrial harmony) (Parasuraman, 2005).

Pengenalan kepada Kod Amalan Keharmonian Industri bertujuan untuk meletakkan prinsip serta garis panduan kepada majikan dan pekerja dalam konteks amalan hubungan industri dan pekerjaan untuk mencapai keharmonian industri yang berterusan. Kandungan utama Kod tersebut merangkumi tanggungjawab, polisi pekerjaan, perundingan kolektif dan komunikasi 
serta konsultasi. Aspek tanggungjawab yang digariskan dalam Kod Amalan Keharmonian Industri meliputi tanggungjawab pihak majikan dan kesatuan majikan, pekerja serta perwakilan mereka iaitu kesatuan sekerja. Garis panduan mengenai tanggungjawab ini bukan sahaja di peringkat organisasi tetapi juga meliputi tanggungjawab di peringkat kebangsaan. Manakala daripada aspek polisi pekerjaan, Kod Amalan Keharmonian Industri telah memberikan garis panduan yang jelas agar pihak majikan serta pekerja memahami polisi-polisi yang diamalkan di organisasi. Polisi pekerjaan yang baik adalah pra-syarat kepada hubungan industri dan pekerjaan yang harmoni.

Oleh itu, amalan seperti pengambilan dan pemilihan pekerja, latihan dan pembangunan, sistem gaji serta jaminan keselamatan pekerjaan merupakan aspek yang perlu dititikberatkan dalam aspek pekerjaan. Selain daripada aspek-aspek tersebut, Kod Amalan Keharmonian Industri turut memberi penekanan terhadap mekanisme penyelesaian pertikaian, mempromosikan amalan yang bersifat kerjasama serta persetujuan bersama (Parasuraman 2005). Kod Amalan Keharmonian Industri telah membantu mewujudkan keharmonian industri khususnya melalui komunikasi yang berkesan dan lebih baik serta kerjasama antara pihak majikan dan pekerja.

\section{Perkembangan era Tun Mahathir Mohammad (1981-2003)}

Pemerintahan Malaysia di bawah Tun Mahathir Mohammad bermula pada tahun 1981 sehingga 2003 telah menyaksikan pelbagai perubahan termasuklah landskap hubungan industri/pekerjaan. Secara umumnya, pada tahun 1980-an, Malaysia telah mengalami perubahan daripada sebuah negara berasaskan pertanian kepada negara perindustrian. Secara lebih terperinci, polisi perindustrian Malaysia pasca-merdeka berubah daripada industri penggantian import (1960-an) kepada industri berorientasikan eksport bermula pada tahun 1970-an hingga 1990-an dan lebih khusus lagi, pihak kerajaan mula memfokuskan kepada industri berat dan industri berasaskan kimia pada tahun 1980-an seiring dengan pembangunan perindustrian di Jepun dan Korea (Wad, 2001). Eksport negara dalam tempoh 1991 hingga 2005 telah meningkat kepada 13.5 peratus dan menjadikan Malaysia di kedudukan ke 18 bagi negara yang mempunyai dagangan yang tertinggi (Asian Development Bank, 2006). Pertumbuhan ekonomi yang mampan telah menjadikan Malaysia sebagai sebuah negara tumpuan terutamanya pelabur asing.

Terdapat pelbagai polisi serta dasar-dasar yang telah dilaksanakan semasa era pemerintahan Tun Dr. Mahathir dan telah memberi impak kepada sistem hubungan industri di Malaysia. Antara pengenalan dasar baru selain daripada meneruskan dasar yang sedia ada seperti Dasar Ekonomi Baru adalah Dasar Pandang Ke Timur dan Dasar Perindustrian. Dasar-dasar tersebut telah memberi impak kepada landskap hubungan industri di Malaysia khususnya daripada aspek perburuhan dan kesatuan sekerja (Anantaraman, 1997; Che Wan Abu Bakar, 2003). 
Pada era pemerintahan Tun Dr. Mahathir, pihak kerajaan giat mempromosikan perindustrian di negara ini. Pelbagai inisiatif yang ditawarkan termasuklah daripada aspek perburuhan. Oleh itu, dalam usaha menawarkan tenaga kerja yang berkualiti maka polisi-polisi berkaitan dengan sumber manusia telah diberikan perhatian (Jomo, 2014). Pihak kerajaan telah melaburkan sejumlah besar peruntukan bagi memastikan sumber manusia yang ada di negara ini mempunyai pengetahuan, kemahiran serta kebolehan. Antaranya adalah meningkatkan kualiti pengajian di peringkat yang lebih tinggi. Walau bagaimanapun, usaha tersebut perlu diteruskan oleh pemimpin negara sekarang sebagai kesinambungan usaha yang telah dibuat oleh pihak yang terdahulu. Tambahan lagi, negara kita masih lagi berdepan dengan kekurangan tenaga kerja yang mahir khususnya di Perusahaan kecil dan sederhana (PKS) (Mok Kim Man, 2012; Zakaria \& Hashim, 2015, 2017).

Dasar Pandang ke Timur dilancarkan pada Februari 1982 oleh Tun Mahathir dengan menjadikan budaya kerja yang cemerlang dalam kalangan masyarakat Jepun dan Korea sebagai sesuatu yang perlu diteladani oleh masyarakat di Malaysia. Objektif utama dasar ini adalah untuk memastikan prestasi pengurusan dan pembangunan negara serta mewujudkan golongan masyarakat yang mempunyai nilai dan etika kerja yang positif dan seterusnya menyumbang kepada produktiviti yang lebih baik. Pelbagai perubahan telah dilakukan termasuklah pengenalan kesatuan sekerja dalaman seperti yang diamalkan di negara Jepun. Pada era pemerintahannya, Tun Mahathir menekankan hubungan yang harmoni antara kesatuan sekerja dan majikan bagi mengekalkan daya saing negara dan Tun Mahathir percaya melalui kesatuan sekerja dalaman dapat membantu organisasi untuk lebih cemerlang (Anantaraman, 1997). Oleh itu, pihak kerajaan giat mempromosikan kesatuan sekerja dalaman seiring dengan dasar tersebut.

Walau bagaimanapun, pelaksanaan konsep kesatuan sekerja dalaman di Malaysia telah mengundang kritikan serta sering dipertikaikan dari aspek keberkesanannya kerana kesatuan sekerja dalaman dilihat tidak mampu menangani masalah-masalah pekerja tetapi seringkali akur dengan polisi yang telah ditetapkan oleh pihak majikan (management-controlled lapdogs) serta dikenal sebagai kesatuan syarikat (Anantaraman, 1997; Mohamed, et. all. 2010). Konsep ini ternyata berbeza dengan konsep kesatuan sekerja dalaman yang diamalkan di Jepun kerana kesatuan sekerja dalaman mereka melibatkan semua pekerja termasuklah pihak pengurusan.

Justifikasi pihak kerajaan dalam mempromosikan model kesatuan sekerja dalaman berbanding model kesatuan sekerja daripada negara barat adalah kerana kewujudan kesatuan sekerja dalaman membantu untuk mewujudkan kesetiaan terhadap organisasi, penekanan terhadap kerjasama pengurusan dan pekerja, orientasi terhadap produktiviti pekerja, perkongsian bersama dan keharmonian di tempat kerja. Dengan kata lain, kesatuan sekerja dalam ini membantu untuk meningkatkan produktiviti organisasi, faedah kepada pekerja serta pembangunan ekonomi negara (Wad, 2001).

Dalam masa yang sama, Kongres Kesatuan Sekerja Malaysia (MTUC) turut memperlihatkan perubahan sikap terhadap pihak kerajaan. Dalam tempoh 1995 hingga 1999 
telah menyaksikan "sikap berbaik-baik" antara pihak MTUC dengan kerajaan (Che Wan Abu Bakar, 2003). Berbanding sebelumnya, pihak MTUC di bawah kepimpinan Dato Zainal Rampak lebih cenderung kepada sikap yang kritis dan telah menentang beberapa dasar yang dilihat merugikan para pekerja khususnya melalui Deklarasi Genting Highland 1989. MTUC telah memperjuangkan banyak isu pekerjaan dan antaranya adalah berkenaan dengan hak pekerja, gaji minimum, pembangunan kemahiran, kemasukan buruh asing, keselamatan dan kesihatan pekerjaan serta isu Kumpulan Wang Simpanan Pekerja (KWSP). Isu mengenai gaji minimum yang diperjuangkan oleh MTUC tidak diterima oleh pihak kerajaan pada waktu tersebut atas alasan gaji minimum boleh menjejaskan kemasukan pelaburan asing (Che Wan Abu Bakar, 2003; Kuruvilla, 1996).

Secara keseluruhan, zaman pemerintahan Tun Mahathir telah membawa pelbagai anjakan bukan sahaja daripada aspek ekonomi, politik serta sosial tetapi juga mempengaruhi pembentukan landskap hubungan pekerjaan di Malaysia. Kewujudan kesatuan sekerja masih dibenarkan tetapi dalam kawalan pihak kerajaan. Tujuan kawalan tersebut adalah untuk memastikan sistem hubungan pekerjaan yang harmoni dapat diwujudkan dan seterusnya menjadi daya penarik kepada pihak pelabur asing untuk datang ke negara ini.

\subsection{Perkembangan Fasa Keempat (2000-2020)}

Ciri utama perkembangan pada fasa keempat ialah perubahan corak pentadbiran yang lebih menjurus kepada konsep fleksibiliti dengan menekankan amalan ketulusan dan integriti. Selain itu, terdapat pelbagai dasar telah dibentuk bagi meneruskan perkembangan ekonomi yang telah berubah dari proses perindustrian kepada ekonomi berasaskan pengetahuan. Kesemua ini telah dilakukan oleh dua orang Perdana Menteri iaitu Tun Abdullah Ahmad Badawi dan Datuk Seri Najib Tun Abdul Razak.

\section{Perkembangan era Tun Abdullah Ahmad Badawi (2003-2009)}

Tun Abdullah Badawi mengambil alih pemerintahan Malaysia bermula pada tahun 2003 sehingga 2009. Dalam tempoh enam tahun pemerintahan, beliau telah melancarkan beberapa dasar serta perubahan tertentu. Antara perubahan yang dilaksanakan diberi perhatian oleh pihak kerajaan adalah berkenaan dengan kerangka yang menyenaraikan langkah-langkah yang untuk dikenal pasti untuk mencapai Wawasan 2020. Salah satu langkah yang telah dikenal pasti adalah berkaitan dengan pembangunan sumber manusia. Pihak kerajaan di bawah Tun Abdullah komited untuk memastikan tenaga kerja mempunyai pengetahuan, kreativiti serta inovasi dan mempunyai "minda kelas pertama" yang memberikan penekanan terhadap pembangunan modal insan yang lebih holistik (Mok Kim Man, 2012). Dengan perkataan lain, masa depan Malaysia bergantung kepada kualiti yang ada pada modal insannya. 
Selain daripada itu, pihak kerajaan turut memperkenalkan sistem penilaian prestasi baru yang dikenali sebagai, key performance indicators (KPIs) bagi memastikan penilaian prestasi dibuat secara telus dan adil. Organisasi-organisasi yang mengamalkan sistem ini telah membuktikan bahawa prestasi mereka lebih baik khususnya dalam menilai pekerja. Antara organisasi luar negara yang telah berjaya setelah mengamalkan sistem KPIs ini termasuklah Boston Beer Co., Mercer Human Resource Consulting dan Avis Rent-a-Car System, Inc.(Mok Kim Man, 2012). Oleh itu, berdasarkan kejayaan yang telah dicapai oleh pihak organisasi tersebut, pihak kerajaan telah melaksanakan KPIs ini bagi menggalakkan peningkatan produktiviti yang lebih baik.

\section{Perkembangan era Datuk Seri Mohd Najib Tun Abdul Razak}

Dasar berkaitan dengan perburuhan pada era pemerintahan Datuk Seri Mohd Najib Abdul Razak yang mendapat perhatian adalah berkenaan dengan Dasar Gaji Minimum yang diumumkan oleh Perdana Menteri dalam Pembentangan Bajet pada 15 Oktober 2010. Tujuan utama penetapan gaji minimum adalah berlandaskan Model Baru Ekonomi (MBE) bagi menjadikan Malaysia sebagai sebuah negara berpendapatan tinggi. Dasar ini antara lainnya adalah bertujuan untuk memastikan para pekerja dapat memenuhi keperluan asas dan menyediakan suasana sesuai untuk industri dalam meningkatkan nilai rantaian pengeluaran mereka (Elangkovan, 2012).

Gaji minimum dalam konteks ini merujuk kepada gaji pokok yang dibayar kepada pekerja, tidak termasuk apa-apa elaun serta bayaran lain. Tujuan utama pihak kerajaan pada masa kini melaksanakan dasar gaji minimum adalah untuk memastikan pendapatan para pekerja melebihi Pendapatan Garis Kemiskinan (PGK) nasional iaitu RM800 selaras dengan matlamat menjadi negara berpendapatan tinggi (Kementerian Sumber Manusia).

Dasar ini telah mendapat pelbagai respon daripada pelbagai pihak. Terdapat pihak-pihak tertentu melihat penguatkuasaan gaji minimum dapat membantu kelangsungan hidup pekerja-pekerja dalam menangani kos sara hidup yang semakin meningkat. Namun, terdapat juga pihak-pihak yang lain meragui keberkesanan pelaksanaan gaji minimum tersebut kerana pelaksanaan tersebut boleh memberi impak yang negatif kepada kadar penggangguran di negara ini (Elangkovan, 2012).

Di sebalik kritikan yang diterima, pihak kerajaan pada tahun 2016, telah mengumumkan peningkatan kadar gaji minimum berbanding pada tahun 2012. Kadar gaji minimum untuk pekerja di Semenanjung telah meningkat daripada RM900 kepada RM1000. Manakala bagi Sabah dan Sarawak, kadar tersebut meningkat daripada RM800 kepada RM920 (Warta Kerajaan Persekutuan, 2016). Pelaksanaan Dasar Gaji Minimum telah mendapat perhatian pihak MTUC kerana mereka telah berjuang untuk mendapatkan gaji minimum ini lebih daripada 20 tahun. Mengikut MTUC pelaksanaan gaji minimum telah menarik ramai pekerja tempatan untuk memohon pekerjaan yang sebelumnya hanya dimonopoli oleh rakyat asing (Bernama, 2014). 


\section{Perkembangan era Tun Dr. Mahathir Mohammad}

Kemenangan Pakatan Harapan pada Pilihanraya Umum ke-14 turut memberi kesan kepada perubahan dasar perburuhan di Malaysia. Perlantikan semula Tun Dr.Mahathir sebagai Perdana Menteri yang ke-7 telah menjadi asas kepada peralihan bagi meningkatkan lagi perlindungan kepada para pekerja di Malaysia. Keadaan ini disebabkan janji yang diberikan dalam Manifesto Pakatan Harapan iaitu untuk membentuk Malaysia Baharu yang terkandung dalam Buku Harapan (2018) yang bertujuan:

Buku ini mengandungi janji-janji kami PAKATAN HARAPAN kepada rakyat Malaysia apabila menubuh Kerajaan. Inilah dasar dan tindakan-tindakan yang akan kami laksana untuk memulih semula dan MEMBINA NEGARA serta MEMENUHI HARAPAN rakyat. Manifesto ini komprehensif dan meliputi setiap perkara yg penting bagi rakyat terbanyak, terutamanya golongan yang memerlukan. Sepanjang masa kami bersedia ditegur dan mendengar pendapat rakyat. Dalam menyediakan manifesto ini, kami telah berunding dengan banyak pihak dari pelbagai lapisan masyarakat. Saya berterima kasih kepada semua yang memberi sumbangan idea yang bernas dan berharga.

Kandungan buku tersebut mengandungi janji-janji yang akan dilaksankan oleh kerajaan Pakatan Harapan. Terdapat beberapa janji yang berkaitan secara langsung dengan aspek perburuhan seperti yang ditunjukkan pada Jadual di bawah.

Jadual 3: Manifesto Pakatan Harapan

\begin{tabular}{|c|c|}
\hline Bil & Perkara \\
\hline Janji 33 & $\begin{array}{l}\text { Menubuhkan Suruhanjaya Peluang } \\
\text { Pekerjaan Saksama }\end{array}$ \\
\hline Janji 34 & Meningkatkan pendapatan rakyat terbanyak \\
\hline Janji 35 & $\begin{array}{l}\text { Menaikkan martabat golongan pekerja dan } \\
\text { mewujudkan lebih banyak pekerjaan } \\
\text { berkualiti }\end{array}$ \\
\hline Janji 36 & $\begin{array}{l}\text { Melaksanakan KWSP untuk suri rumah } \\
\text { Janji }\end{array}$ \\
\hline Janji 37 & $\begin{array}{l}\text { Menjamin kesejahteraan rakyat jangka } \\
\text { panjang }\end{array}$ \\
\hline
\end{tabular}

Sumber: Buku Harapan (2018)

(https://kempen.s3.amazonaws.com/pdf/Buku_Harapan.pdf)

Berdasarkan janji-janji tersebut, beberapa perubahan telah dilakukan terutama sekali yang melibatkan pindaan terhadap perundangan berkaitan pekerjaan dan perburuhan. Tanggungjawab ini telah diberikan kepada Menteri Sumber Manusia yang antara lain menegaskan bahawa: 
"Beliau berkata, pihaknya juga akan meminda lima akta lain, termasuk Akta Kesatuan Sekerja 1959 dan Akta Perhubungan 1967, dalam masa terdekat. "Berkenaan pindaan Akta Kerja, kementerian sudah mengadakan beberapa perbincangan dengan pihak berkepentingan dan kita sudah memperhalusinya. Susulan perbincangan itu, kementerian bercadang membuat beberapa perubahan dan sedang menunggu kelulusan Peguam Negara untuk diputuskan Kabinet," (Berita Harian.com , 6.8.2019)

https://www.bharian.com.my/berita/nasional/2019/08/593353/akta-kerja-1955disemak-untuk-pindaan

Perubahan ini telah dibincangkan dalam Majlis Penasihat Buruh Kebangsaan dan telah bersetuju untuk meminda beberapa perkara dalam Akta 177. Tujuan perubahan tersebut adalah:

Pindaan Akta Perhubungan Perusahaan 1967 adalah sebahagian daripada Janji Nombor 35 Manifesto Pilihanraya Pakatan Harapan yang antara lain adalah untuk memastikan perlindungan hak pekerja setara dengan standard perburuhan antarabangsa dan mematuhi konvensyen yang ditetapkan oleh Pertubuhan Buruh Antarabangsa. Kementerian juga sedang mengkaji beberapa undang-undang buruh yang lain termasuk Akta Kerja 1955 dan Akta Kesatuan Sekerja 1959 yang dijangka akan dibentangkan tidak lama lagi. (Siaran Akhbar Kementerian Sumber Manusia, 7.10.2019) http://hrnews.my/wp-content/uploads/2019/10/KenyataanMedia-Cadangan-Pindaan-Akta-177.pdf

Sehubungan dengan itu, terdapat 9 perkara yang akan dipinda pada akta tersebut yang secara keseluruhannya adalah untuk menambahbaik jaminan dan perlindungan kepada pekerja. Diantara perkara tersebut yang berkaitan dengan kesatuan sekerja ialah:

Jadual 3: Pindaan Akta Perhubungan Perusahaan, 1967 tahun 2019

\begin{tabular}{|l|l|c|}
\hline \multicolumn{1}{|c|}{ Perkara } & \multicolumn{1}{|c|}{ Tajuk Pindaan } & Seksyen Akta 177 \\
\hline Pindaan 3. & Menambahbaik Proses Tuntutan Pengiktirafan & $9-12$ \\
\hline Pindaan 4 & Hak Berunding Tunggal & $2-8$ \\
\hline Pindaan 5 & $\begin{array}{l}\text { Membenarkan Kesatuan Sekerja } \\
\text { Membangkitkan Secara Umum Isu-Isu } \\
\text { Berkaitan Hak Istimewa Majikan }\end{array}$ & 13 \\
\hline Pindaan 6 & $\begin{array}{l}\text { Memperkenalkan Pengecualian sebelum } \\
\text { Perkara berkaitan Perundingan Dirujuk ke } \\
\text { Mahkamah Perusahaan }\end{array}$ & 18 \\
\hline
\end{tabular}

Sumber: Disusun berdasarkan Siaran Akhbar Kementerian Sumber Manusia http://hrnews.my/wp-content/uploads/2019/10/Kenyataan-Media-CadanganPindaan-Akta-177.pdf 
Journal of Borneo Social Transformation Studies (JOBSTS), Vol. 5. No. 1, 2019

ISSN 2462-2095

Universiti Malaysia Sabah

Pindaan-pindaan tersebut secara ringkas akan mengurangkan karenah birokrasi dengan menghapuskan kuasa Menteri Sumber Manusia dalam proses penyelesaian sesuatu pertikaitan perusahaan. Antaranya berkaitan dalam proses pengktirafan kesatuan sekerja dan penghapusan campurtangan dari Jabatan Hal Ehwal Kesatuan Sekerja. Selain itu, pindaan baru ini akan membolehkan kewujudan lebih dari satu kesatuan sekerja dalam sesebuah organisasi dan memberikan kuasa kepada kesatuan sekerja dalam mempersoalkan secara umum berkaitan hak prerogatif pihak majikan.

Berdasarkan kepada perkembangan ini, sikap dan perubahan kerajaan baharu menunjukkan bahawa proses pemerkasaan golongan pekerja akan diteruskan.

\subsection{Analisis dan Perbincangan}

Penjelasan berkaitan perkembangan hubungan antara kepimpinan, dasar perburuhan dan kesatuan sekerja pada bahagian dapatan kajian menunjukkan suatu kesinambungan pentadbiran oleh Perdana Menteri yang disesuaikan dengan tahap pembangunan ekonomi negara. Tahap tersebut adalah serupa seperti yang berlaku di kebanyakan negara maju iaitu perubahan tumpuan ekonomi dari sektor pertanian kepada sektor perindustrian. Berdasarkan perkembangan tersebut, kajian ini mendapati bahawa perubahan dalam dasar pembangunan negara turut menyumbang kepada perubahan dalam dasar berkaitan perburuhan. Terdapat dua bentuk perubahan iaitu perubahan sistem perhubungan perusahaan berasaskan konsep 'voluntary' kepada 'compulsory arbitration'. Perubahan kedua ialah berkaitan perubahan bentuk kesatuan sekerja yang bersifat kebangsaan kepada kesatuan bersifat dalaman. Perubahan-perubahan tersebut telah memberi kesan kepada kelangsungan kesatuan sekerja.

Perubahan sistem hubungan industri yang bersifat 'timbang tara wajib' merupakan asas kepada pembentukan keharmonian dalam perhubungan perusahaan. Matlamat ini dapat dicapai disebabkan ciri 'musyawarah' yang menekankan kepentingan campur tangan pihak ketiga bagi menyelesaikan pertikaian perusahaan (Ahmad, 2004). Dengan itu, pihak kesatuan tidak akan cenderung untuk melancarkan tindakan perusahaan sebaliknya mengambil pendekatan yang lebih sederhana bagi menuntut sesuatu tuntutan kepada pihak majikan (Ahmad \& Bustami, 2017b). Sebagai contohnya dalam proses perundingan kolektif, pihak kesatuan mempunyai kecenderungan untuk mengamalkan teknik perundingan yang bersifat 'menang-menang' (Yussof, 2014). Kesannya akan membantu kerajaan untuk menarik lebih ramai pelabur luar untuk melabur di Malaysia.

Perubahan kedua ialah berkaitan perubahan struktur kesatuan sekerja yang lebih cenderung untuk wujud sebagai kesatuan dalaman. Ciri ini adalah berbeza dengan perkembangan yang berlaku pada fasa penjajahan, awal kemerdekaan sehingga tahun 1970. Meskipun terdapat kesatuan induk sebagai 'payung' kepada kesatuan sekerja, namun hubungan tersebut adalah terhad dan setiap kesatuan dalaman adalah tertakluk kepada sistem dalaman tempat mereka 
bekerja. Keadaan ini memberi kesan terhadap bidang kuasa kesatuan yang terhad kepada skop pekerjaan mereka sahaja menyebabkan 'solidariti' di kalangan pekerja semakin lemah. Selain itu, terdapat beberapa kritikan berkaitan kesatuan dalaman seperti yang ditegaskan oleh Wad (2001:5) bahawa:

"The rationale of the government's in-house union policy is the same today as it was at the time of inception. The government claims that, contrary to the Western model of industrial unionism, the Japanese model of enterprise unionism facilitates company loyalty and corporate mentality, management-labour collaboration, productivity orientation of employees, mutual sharing and industrial harmony at the enterprise level. Hence, enterprise unionism facilitates company profitability, labour benefits and national economic development. Critics point out that in-house unions in comparison with industrial unions are "company unions", i.e. weak, "yellow" or management-controlled lapdogs, more or less unable to defend and improve employees' rights and interests, and that they may even not be "dynamically efficient" in the sense that they do not provide for concomitant wage and productivity increases (Standing 1991, 1992a, 1992b; for an alternative view Wad 1996, 1997a, 1998)."

Berdasarkan kepada kenyataan tersebut, beberapa implikasi kajian dapat dikenal pasti. Pertama berkaitan pengaruh corak kepimpinan tertinggi negara terhadap pergerakan kesatuan sekerja. Implikasi kedua adalah berkaitan kelangsungan kesatuan sekerja di Malaysia dan yang terakhir adalah terhadap sistem perhubungan perusahaan di Malaysia. Implikasi berkaitan pengaruh corak kepimpinan Perdana Menteri terhadap kesatuan sekerja menunjukkan bahawa dasar berkaitan perburuhan adalah termasuk dalam dasar-dasar pembangunan utama negara. Oleh itu, corak pentadbiran seseorang Perdana Menteri akan turut mempengaruhi pembentukan dasar dan perancangan pembangunan negara. Contohnya corak berasaskan konsep 'diplomasi' telah mempengaruhi dasar buruh pada era pentadbiran Tunku Abdul Rahman. Sehubungan dengan itu, penerimaan terhadap 'gerakan kesatuan sekerja' turut dipengaruhi oleh sikap tersebut yang dijelmakan dalam dasar-dasar yang telah dibentuk.

Selain itu, dari sudut implikasi terhadap kelangsungan kesatuan sekerja adalah berkaitan keperluan untuk memperkasakan institusi tersebut dengan mengembalikan semula peranannya seperti pada awal kemunculan kesatuan. Pelbagai dasar yang dikatakan sebagai menyekat perkembangan kesatuan perlu dinilai semula seperti 'kesatuan dalaman' dan kebebasan pekerja akan dapat mengembalikan keinginan pekerja untuk berkesatuan. Demikian juga dengan fungsi kesatuan induk yang perlu dikuatkan sebagai sebuah kesatuan yang didaftarkan di bawah Akta Kesatuan Sekerja 1959.

Implikasi tersebut akhirnya akan turut menyumbang kepada perubahan dalam sistem perhubungan perusahaan di Malaysia yang akan berubah kepada sistem berpusat (centralised). Perubahan ini adalah seperti yang ditegaskan oleh Wad (2001) berkaitan kewujudan sistem Hubungan Industri bersifat desentralisasi (convergent dan divergent) yang bermula sejak tahun 1980-an. Wad (2001:5) menegaskan bahawa: 
"In sum, the Malaysian system of industrial relations was decentralised in both relational and organisational terms in the long term. Centralised collective bargaining withered with the economic and employment decline of the plantation industry, and the removal of centralised bargaining in the manufacturing and service industries. Centralised unionism (and union density) declined from its peak in the general unionism of 1947-48, while enterprise unions mushroomed during the 1980s. Yet, in absolute terms union membership grew and changed in terms of sector composition. Moreover, the trade union centre, the Malaysian Trades Union Congress (MTUC), is still dominated by the bigger national unions, and the trade union field in Malaysia is today composed of pluralistic and competing union organisations, engaged in enterprise-based collective bargaining with individual employers. The economic crisis in 1997-99 did not seem to change that situation overnight."

Berdasarkan implikasi tersebut, terdapat keperluan bagi kajian yang lebih mendalam berkaitan hubungan antara corak pentadbiran kepimpinan tertinggi negara dan hubungannya dengan dasar perburuhan yang akhirnya akan memberi kesan kepada kesatuan sekerja. Kajian awal ini merupakan analisis terhadap pelbagai hasil kajian terdahulu dan memerlukan kajian lanjut yang melibatkan pelbagai pihak dalam perhubungan perusahaan.

\subsection{Kesimpulan}

Analisis hubungan antara kepimpinan, dasar perburuhan dan kesatuan sekerja dalam kerta kerja ini menunjukkan perubahan peranan kesatuan sekerja yang bermula sebagai organisasi yang berpengaruh dan penting dalam pembentukan dasar perburuhan negara. Namun begitu, kesan dasar tersebut sebaliknya menyebabkan kesatuan telah berubah menjadi organisasi yang kurang berpengaruh dan mempunyai peranan yang terhad disebabkan sifatnya sebagai kesatuan dalaman. Kekurangan itu telah diimbangi dengan mewujudkan MTUC dan CUEPACS sebagai satu gabungan di peringkat kebangsaan dan telah melakukan pelbagai usaha untuk membela kepentingan pekerja. Namun begitu, tindakan institusi tersebut juga adalah terbatas disebabkan sifatnya yang berbeza dengan sebuah kesatuan sebenar dalam konteks perhubungan pekerjaan. Berdasarkan keterbatasan itu, perubahan terhadap dasar perburuhan perlu dinilai semula agar lebih fleksibel terhadap perkembangan kesatuan sekerja. Perubahan ini dapat dilakukan sekiranya pemimpin tertinggi negara dapat mengembalikan 'semangat' dan 'sikap' perdana menteri sebelum ini.

\section{Rujukan}

Ahmad, M. (2004). Timbangtara Pertikaian Perusahaan di Malaysia: Satu Analisis Konflik. Universiti Kebangsaan Malaysia.

Alatas, H. (1988). Mitos pribumi malas: citra orang Jawa, Melayu dan Filipina dalam kapitalisme kolonial. Kuala Lumpur: Dewan Bahasa dan Pustaka.

Anantaraman, V. (1997). Malaysian Industrial Relations: Law and Practice. Kuala Lumpur: 
Journal of Borneo Social Transformation Studies (JOBSTS), Vol. 5. No. 1, 2019

ISSN 2462-2095

Universiti Malaysia Sabah

Universiti Putra Malaysia.

Arokia, D. (1991). Not Beyond Repair, Reflections of a Malaysian Trade Unionist. Hong Kong: Asia Monitor Resource Center.

Che Wan Abu Bakar, W. T. (2003). Kepimpinan MTUC dan hubungan perusahaan. Shah Alam: Karisma Publications Sdn.Bhd.

Elangkovan, K. (2012). Minimum Wage Laws in Malaysia: An Answer to the Increasing Rate of Unemployment. International Journal of Academic Research in Economics and Management Sciences, 1(5), 135-147.

Fong Leong Yee. (1999). Labour and Trade Unionism in Colonial Malaya. A Study of the SocioEconomic and Political Bases of the Malayan Labour Movement, 1930-1957. Universiti Sains Malaysia.

Gamba, C. (1962). The origins of trade Unionism in Malaya. Singapura: Eastern Universities Press.

Institut Tadbiran Awam Negara (INTAN). (1994). Institut Tadbiran Awam Negara (INTAN). Kuala Lumpur: INTAN.

Jomo, K. ., \& Todd, P. (1994). Trade Unions and the State in Peninsular Malaysia. Oxford University Press. Kuala Lumpur: Oxford University Press.

Jomo, \& Todd, P. (1996). Trade Unions and the State in Peninsular Malaysia. The Journal of Asian Studies 1, 55(1), 218-219.

Kee Mohd Yussof, K.Y.S (2014). Pendekatan pengurusan konflik dan hubungannya dengan amalan interest based bargaining ( IBB): kajian ke atas pemimpin kesatuan sekerja sektor perindustrian di Sabah, Journal of Techno Social 6(2), 63-80.

Kee Mohd Yussof, K.Y.S. Zakaria, N. \& Ahmad, M. (2015). Transformasi kesatuan sekerja di Malaysia:isu, cabaran dan masa depan. Persidangan Transformasi Sosial ke-2, 25-26 November, Fakulti Kemanusiaan Seni dan Warisan, UMS

Kee Mohd Yussof, K.Y.S. (2014). Pendekatan Pengurusan Konflik dan Hubungannya dengan Amalan Interest Based Bargaining (IBB): Kajian Ke Atas Pemimpin Kesatuan Sekerja Sektor Perindustrian Di Sabah, 6(2), 63-80.

Kee Mohd Yussof, K. Y. S., Zakaria, N. S., \& Ahmad, M. (2015). Transformasi kesatuan sekerja: Isu, cabaran dan masa depan. In Persidangan Transformasi Sosial ke 2.

Kementerian Sumber Manusia. (2019) Kenyataan Media: Cadangan pindaan terhadap akta perhubungan perusahaan 1967 [akta 177] http://hrnews.my/wp-content/uploads/2019/10/Kenyataan-Media-Cadangan-Pindaan-Akta177.pdf

Kuruvilla, S. (1996). Linkages Between Industrialization Strategies and Industrial Relations/Human Resource Policies: Linkages Between Industrialization Strategies and Industrial Relations/Human Resource Policies: Singapore, Malaysia, the Philippines, and India Industrial Rela. Cornell University ILR School, 1-19.

Kuruvilla, S., \& Erickson, C. L. (2002). Change and transformation in Asian industrial relations. Industrial Relations, 41(2), 171-227.

Mohamed., L. S., \& Chen, V. S. (2011). Trade unions in Malaysia. Malaysia: CCh Asia.

Mohamed, S., Mohd Shamsudin, F., \& Johari, H. (2010). Union organisation and effectiveness: An empirical study on in-house union in Malaysia. Akademika, 78(Salamon 2000), 89-94. Mohammed, N. (2005). A Brief Look At The Malaysian Prime Ministers' Leadership Styles. 
Journal of Borneo Social Transformation Studies (JOBSTS), Vol. 5. No. 1, 2019

ISSN 2462-2095

Universiti Malaysia Sabah

http://jas.uitm.edu.my/images/2005_JUNE/2.pdf.

Mok Kim Man, M. (2012). Malaysia Human Resource Development (HRD) Needs: Challenges and Suggestions. International Journal of Management \& Innovation, 4(2), 41-53.

Norrasyidah Arshad, N. (2019) Akta Kerja 1955 disemak untuk pindaan, Berita Harian.Com 6.10.2019, https://www.bharian.com.my/berita/nasional/2019/08/593353/akta-kerja-1955disemak-untuk-pindaan

Pakatan Harapan. (2018) Buku Harapan. Atas Talian.. https://kempen.s3.amazonaws.com/pdf/Buku_Harapan.pdf

Parasuraman, B. (2005). Communication and consultation in Malaysia: Impact of the 1975 Code of Conduct. In R. C. and M. W. Marian Baird (Ed.), Reworking Work Airaanz 05 Proceedings Of the 19 Conference of The Accociation Of Industrial Relations Academics Of Australia \& New Zealand (pp. 431-439).

Parasuraman, B., \& Satrya, A. (2009). The present scenario of Malaysia and Indonesia Industrial Relations: Accomodation or conflictual Asian profile, 37(1), 35-54.

Parmer, J. N. (1957). Trade Unions in Malaya. The ANNALS of the American Academy of Political and Social Science, 310(1), 142-150.

Raduan Che Rose, Naresh Kumar, N. R. (2011). Trade Union In Malaysia: Perspektives Of Employers \& Employees of Unionized Companies. Indian Journal of Industrial Relations, 46(3), 384-395.

Rowley, C., \& Bhopal, M. (n.d.). The ethnic factor in state-labour relations: The case of Malaysia.

Said, F., \& Zakaria, R. H. (2002). The determinants of trade union. IIUM Journal of Economics and Management, 2(2).

Said, K. (1992). Hubungan Perusahaan di Malaysia 1996-1970. Kuala Lumpur: Dewan Bahasa Pustaka.

Stenson, M. R. (1977). Industrial Conflict in Malaya; Prelude to the Communist Revolt of 1948. Singapore: Oxford University Press.

Sundaram, J. K. (2014). "Malaysia Incorporated": Corporatism a la Mahathir. Institutions and Economies, 6(1), 73-94.

Tan Kwang How. (2011). Human Resource Management in Malaysia: Theory \& Practice. Malaysia: Mc Graw Hill Education.

Wad, P. (2001). Transforming Industrial Relations: the Case of the Malaysian Auto Industry. CLARA Working Paper, (12), 1-30.

Warta Kerajaan Persekutuan. (2016). Perintah Gaji Minimum 2016.

Zakaria, N. S., \& Hashim, M. K. (2015). The impact of employment relations practices on performance of Malaysian SMEs: the conceptual framework. In The 4th International Seminar on Entrepreneurship and Business (Vol. 4, pp. 91-107). UMK.

Zakaria, N. S., \& Hashim, M. K. (2017). Amalan hubungan pekerjaan di perusahaan kecil dan sederhana (pks) di sektor perkilangan di Malaysia. In Simposium Psikologi dan Kesihatan Sosial-I 2017 (SPKS-I 2017). Kota Kinabalu: Universiti Malaysia Sabah.

\section{Senarai Statut}

Akta Kesatuan Sekerja 1959 
Journal of Borneo Social Transformation Studies (JOBSTS), Vol. 5. No. 1, 2019 ISSN 2462-2095

Universiti Malaysia Sabah

Akta Perhubungan Perusahaan 1969 